\title{
Catalase C-262T Gene Variant in Patients with Bronchial Asthma
}

\author{
Milena Despotović ${ }^{1}$, Tatjana Jevtović Stoimenov ${ }^{1}$, Ivana Stanković², \\ Jelena Bašić1 ,Branka Đorđević1 ${ }^{1}$, Dušica Pavlović ${ }^{1}$ \\ ${ }^{1}$ University of Niš, Faculty of Medicine, Department of Biochemistry, Niš, Serbia \\ ${ }^{2}$ Clinical Centre Niš, Clinic for Pulmonary Diseases and Tuberculosis Knez Selo, Niš, Serbia
}

\section{SUMMARY}

Bronchial asthma (BA) is a chronic inflammatory disease of the airways in the pathogenesis of which oxidative stress has a very important role. Single nucleotide polymorphisms (SNPs) in catalase gene may result in decreased antioxidative defense capacity, and thus a higher risk for BA development. Since oxidative stress has an important role in the pathogenesis of BA and catalase has a key role in antioxidant defense, the aim of this study was to examine the association of CAT C-262T polymorphism with BA in Serbian patients with BA.

A total of 170 subjects (79 patients with BA and 91 controls) were screened for CAT C-262T SNP using PCRRFLP method.

The analysis of genotype distribution did not show statistically significant differences between BA patients and controls $(p>0.05)$. Moreover, no differences were detected when comparison was performed based on dominant or recessive model. The distribution of CAT-262C and CAT-262T alleles did not show differences between patients and healthy controls $(\mathrm{p}=0.715 ; \mathrm{OR}=1.091 ; 95 \% \mathrm{CI}=0.684-1.741)$. Further analysis of genotype and allele distributions, based on stratification by sex, did not show significant differences between BA patients and controls $(\mathrm{p}>0.05)$.

This is the first study that examined CAT C-262T (rs1001179) SNP in Serbian patients with BA. The results obtained in this study showed that biallelic SNP at the position -262 in the catalase gene is not associated with BA in the Serbian population.

Key words: bronchial asthma, SNP, catalase, oxidative stress 


\section{INTRODUCTION}

Bronchial asthma (BA) is a complex chronic inflammatory disease of the airways, the pathophysiology of which is not completely understood. It is considered that BA is a result of complex interaction between different genetic and environmental factors. Lungs are prone to damage caused by reactive oxygen species (ROS) due to the large surface that is directly exposed to high oxygen pressure and different irritants. Moreover, the lungs are exposed to microbes and the process of their elimination in order to keep airways sterile results in higher ROS production (1). High ROS levels, caused by increased ROS production or/and decreased antioxidant cellular capacity, results in oxidative stress which subsequently induces direct or indirect ROS-mediated damage of lipids, proteins and nucleic acids (2). Oxidative stress increases inflammation and bronchial hyperreactivity, stimulates bronchospasm and increases mucussecretion in BA (3).

An adequate induction of antioxidant mechanisms is of great importance for the homeostasis of cellular functions. Under the physiological conditions, different enzymatic (catalase, superoxide-dismutase, glutathione peroxidase) and non-enzymatic (vitamins $C$ and $\mathrm{E}$, glutathione, bilirubin, coenzyme Q) antioxidant systems keep reducing the redox state. Catalase (E.C.1.11.1.6) is an antioxidant enzyme that decomposes hydrogen peroxide $\left(\mathrm{H}_{2} \mathrm{O}_{2}\right)$ to molecular oxygen and water. It is present in almost all mammalian cells, mainly in peroxisomes and mitochondria with an exception of erythrocytes where enzyme is located in cytoplasm. However, catalase may be released into the extracellular environment where it has the potential to function as antioxidant and regulator of cell survival (4). Catalase is especially active in the presence of high concentrations of $\mathrm{H}_{2} \mathrm{O}_{2}$, but in a prolonged oxidative stress its activity notably decreases due to the oxidation of NADP to $\mathrm{NADP}+(1)$.

Human catalase is coded by the gene located on the short arm of the chromosome 11. It consists of 13 exons and 12 introns and codes 256 amino acid long protein. Catalase gene contains 8 transcription initiation sites, 3 CCAAT and 3 GC-like boxes, but it does not contain TATA box,initiating consensus sequence in the promoter region, which results in the numbers of transcription initiation sites (5). The regulation of catalase gene expression significantly influences the total amount of the enzyme and it is regulated by the different mechanisms involving peroxisome proliferator-activated receptor gamma (PPAR $\gamma$ ), tumor necrosis factor $\alpha$ (TNF$\alpha)$, p53 and CpGhypermethylation in the promoter of catalase gene (6).

Single nucleotide polymorphisms (SNPs) located in genes coding the antioxidant enzymes may modify the inter-individual variability in the defense capacity against oxidative stress by altering enzymes structure, substrate specificity or enzyme activity (7). One of the common polymorphisms in catalase gene (CAT C-262T, rs1001179) leads to the substitution of cytosine (C) by thymine (T) at the position -262. This SNP is located in the promoter region of catalase gene and may influence transcription by changing the binding of transcription factors, and thus alter basal catalase expression in differrent cell types (6). Homozygous mutant genotype CAT$262 \mathrm{TT}$ could be associated with reduced antioxidant defense, and thus, increased oxidative stress in BA. However, the precise role of this SNP in BA is still not elucidated.

Since oxidative stress has an important role in the pathogenesis of BA and catalase has a key role in antioxidant defense, the aim of this study was to examine the association of CAT C-262T polymorphism with BA in the Serbian patients with BA.

\section{MATERIALS AND METHODS}

\section{Patients}

A total of 170 subjects, inhabitants of the southeast Serbia, were enrolled in this study. All participants were divided into two groups:

- Group I included 79 patients with BA (32 male and 47 female; mean age $47.48 \pm 15.81$ years) diagnosed at the Clinic for Pulmonary Diseases and Tuberculosis Knezselo, Clinical Center Niš, Serbia. Bronchial asthma was diagnosed according to GINA (Global Initiative for Asthma) protocol.

- Group II included 91 unrelated healthy volunteers (45 male and 46 female; mean age $46.81 \pm 16.78$ years). Control group involved healthy volunteers without previous history of BA and/or atopy, as well as the absence of other acute and chronic diseases.

All individual participants included in the study signed an informed consent prior to study entry. This study was conducted in accordance with the principles of the Declaration of Helsinki and the good laboratory practice, and was approved by the Ethical Committee of the Faculty of Medicine, University of Niš, Serbia.

\section{Samples}

Blood samples were collected in the vacutainers with ethylenediaminetetraacetic acid (EDTA) as an anticoagulant during the routine laboratory testing by the cubital vein punction. DNA was isolated from $200 \mu \mathrm{l}$ of the whole blood according to the manufacturer protocol (QIAamp DNA Blood Mini Kit, Quiagen $\mathrm{GmbH}$, Hilden, Germany) and stored at $-20{ }^{\circ} \mathrm{C}$ until further experiments were performed. 


\section{SNP genotyping}

The CAT C-262T polymorphism was determined using polymerase chain reaction - restriction fragment length polymorphism (PCR-RFLP) technique. PCR was performed in a final volume of $25 \mu \mathrm{l}$ containing $20 \mathrm{ng}$ of DNA, $12.5 \mu$ KAPA2G Fast HotStartReadyMix (Kapa Biosystems, Inc, USA) and 20 pmol of each primer (F 5'TAA GAG CTG AGA AAG CAT AGC T-3'; R 5'-AGA GCC TCG CCC CGC CGG ACC G-3'). Initial denaturation step at $95{ }^{\circ} \mathrm{C}$ for 2 min was followed by 35 cycles of denaturation step at $95{ }^{\circ} \mathrm{C}$ for $15 \mathrm{~s}$, annealing step at $63{ }^{\circ} \mathrm{C}$ and extension step at $72{ }^{\circ} \mathrm{C}$ for $15 \mathrm{~s}$. Final extension step was performed at $72{ }^{\circ} \mathrm{C}$ for $1 \mathrm{~min}$. The obtained PCR products were identified by $2 \%$ agarose gel electrophoresis. Gels were stained with ethidium bromide and visualized under UV light. Afterwards, the obtained PCR products were digested at $37{ }^{\circ} \mathrm{C}$ for 15 min using FastDigestSmaI restriction enzyme (Fermentas GmbH, St. Leon-Rot, Germany) and analyzed by $8 \%$ polyacrylamide gel electrophoresis. The genotype was denoted as mutant homozygous or TT if $185 \mathrm{bp}$ band was detected, heterozygous or CT if three bands were detected (185 bp, $155 \mathrm{bp}$ and $30 \mathrm{bp}$ ) and wild type or CC if $155 \mathrm{bp}$ and $30 \mathrm{bp}$ bands were detected.

All genotype analyses were performed by two independent researchers. After the polymorphic alleles were established to be homozygous for the mutant genotype, the PCR-RFLP was repeated in order to confirm the obtained results.

\section{Statistical analysis}

Chi-square $\left(\chi^{2}\right)$ test or two-tailed Fisher's test, when the number of expected cases was small, was used for testing the differences in genotype and allele frequencies between patients and controls. The genetic risk magnitudes were assessed by calculating odds ratios (OR) with 95\% confidence intervals (95\% CI). Probability values $\mathrm{p}<0.05$ were considered significant.

\section{RESULTS}

The genotype frequencies for CAT C-262T SNP were in Hardy-Weinberg equilibrium ( $p>0.05)$, except for female patients with BA where genotype distribution was not in Hardy-Weinberg equilibrium ( $\mathrm{p}<0.05)$.

The most frequent genotype in BA patients was heterozygous CT with $48.10 \%$. Homozygous CC genotype was detected in $45.57 \%$, while mutant TT genotype was detected in only $6.33 \%$ of BA patients. The distribution of genotypes in controls was as follows: $50.55 \%$ CC, $41.76 \%$ CT and $7.69 \%$ TT. The analysis of genotype distribution did not show statistically significant differences between BA patients and healthy controls (Table 1).

Table 1. Distribution of rs1001179 genotypes in bronchial asthma patients and controls

\begin{tabular}{c|c|c|c|c|c|c}
\hline \hline Model & rs1001179 & BA & Control & $\chi^{2}$ & $d f$ & $p$ \\
\hline \multirow{3}{*}{ Codominant } & CC & 36 & 46 & & & \\
& CT & 38 & 38 & 0.709 & 2 & 0.701 \\
& TT & 5 & 7 & & & \\
\hline \multirow{2}{*}{ Dominant } & $\mathrm{CC}$ & 36 & 46 & \multirow{2}{*}{0.402} & 1 & 0.517 \\
& $\mathrm{CT}+\mathrm{TT}$ & 43 & 45 & & & \\
\hline \multirow{2}{*}{ Recessive } & $\mathrm{TT}$ & 5 & 7 & \multirow{2}{*}{0.120} & 1 & 0.729 \\
& $\mathrm{CC}+\mathrm{CT}$ & 74 & 84 & & & \\
\hline \hline
\end{tabular}

BA - bronchial asthma; $\chi^{2}$ - chi-square test; $d f$ - degrees of freedom; $p$ - $p$-value

Moreover, no differences were detected when comparison was performed based on dominant and recessive model (Table 1 ). No significant difference in the distribution of CAT-262C and CAT-262T alleles between patients and healthy controls were observed $(\mathrm{p}$ $=0.715 ; \mathrm{OR}=1.091 ; 95 \% \mathrm{CI}=0.684-1.741$; Table 2). 
Table 2. Distribution of rs1001179 alleles in bronchial asthma patients and controls

\begin{tabular}{|c|c|c|c|c|c|c|}
\hline rs1001179 & $\begin{array}{c}\text { BA } \\
\text { n (\%) }\end{array}$ & $\begin{array}{c}\text { Control } \\
\text { n (\%) }\end{array}$ & $\chi^{2}$ & OR & $95 \% \mathrm{CI}$ & $p$ \\
\hline \multirow[t]{2}{*}{$\mathrm{C}$} & $110(69.62)$ & $130(71.43)$ & & & & \\
\hline & & & 0.133 & 1.091 & $0.684-1.741$ & 0.715 \\
\hline $\mathrm{T}$ & $48(30.38)$ & $52(28.57)$ & & & & \\
\hline
\end{tabular}

$\mathrm{n}$ - number of subjects; BA - bronchial asthma; $\chi^{2}$ - chi-square test; OR - odds ratio;

$\mathrm{CI}$ - confidence interval; $p-p$-value

Table 3 represents the distribution of CAT C-262T genotypes and alleles in BA and controls stratified by sex. The analysis of genotype and allele distributions, based on stratification by sex, did not differ significantly between BA patients and healthy controls $(p>0.05)$.

Table 3. Distribution of rs1001179 genotypes and alleles in bronchial asthma patients and controls stratified by sex

\begin{tabular}{|c|c|c|c|c|c|}
\hline \multirow{2}{*}{\multicolumn{2}{|c|}{ rs1001179 }} & \multicolumn{2}{|c|}{ BA } & \multicolumn{2}{|c|}{ Control } \\
\hline & & $\begin{array}{c}M \\
\text { n (\%) }\end{array}$ & $\begin{array}{c}\text { F } \\
\text { n (\%) } \\
\end{array}$ & $\begin{array}{c}M \\
\text { n (\%) }\end{array}$ & $\begin{array}{c}\text { F } \\
\text { n (\%) }\end{array}$ \\
\hline \multirow{3}{*}{ Genotype } & $\mathrm{CC}$ & $15(46.87)$ & $21(44.68)$ & $22(48.89)$ & $24(52.17)$ \\
\hline & $\mathrm{CT}$ & $13(40.63)$ & $25(53.19)$ & $19(42.22)$ & $19(41.30)$ \\
\hline & TT & $4(12.5)$ & $1(2.13)$ & $4(8.89)$ & $3(6.52)$ \\
\hline \multirow{2}{*}{ Alleles } & $\mathrm{C}$ & $43(67.19)$ & $67(71.28)$ & $63(70.00)$ & $67(72.83)$ \\
\hline & $\mathrm{T}$ & $21(32.81)$ & $27(28.72)$ & $27(30.00)$ & $25(27.17)$ \\
\hline
\end{tabular}

$\mathrm{M}$ - male; F - female; BA - bronchial asthma; $\mathrm{n}$ - number of subjects

\section{DISCUSSION}

Catalase, together with other antioxidativeenzymes, such as superoxide dismutase and glutathione peroxidase, represents the first line enzymatic defense from oxidative stress. Single nucleotide polymorphisms in the catalase gene may alter the susceptibility to oxidative stress-mediated injury. Since it was previously shown that BA is a complex disease associated with increased oxidative stress, the aim of this study was to examine the possible association of catalase C-262T SNP with BA.

SNPs located in genes that code the antioxidative enzymes, such as catalase, may be responsible for altered enzyme structure, substrate specificity or enzyme's activity, and thus, modified defense capacity against oxida- tive stress. Experimental studies showed that catalase activity is up to $50 \%$ lower in bronchoalveolar lavage of asthmatic lungs compared to healthy controls, which is considered to be the result of protein oxidative modification and not the decreased amount of enzyme $(1,8)$. Moreover, erythrocytes of the asthmatic children showed decreased catalase activity compared to healthy children (9).

Among more than 200 SNPs identified in catalase gene (e.g. A-21T - rs793316; C-262T - rs1001179 and C$844 \mathrm{~T}$ - rs769214) C-262T is the most studied. This polymorphism has been studied in different populations and in different pathophysiological conditions giving contradictory results. CAT C-262T is located in the promoter region of catalase gene and it is suggested that this SNP may influence transcription by changing the binding of 
transcription factors leading to altered basal catalase expression in different cell types (6). The association of mutant CAT-262T allele with acatalasia has been previously shown (10). It was also shown that carriers of CAT-262CC had higher activity of CAT compared to those with -262CT or -262TT genotypes $(11,12)$.

Homozygous CAT-262TT genotype was present in $22.6 \%$ of children with BA compared to $4.8 \%$ healthy children in the Slovak population (13). Similar distribution of CAT C-262T genotypes was observed in European population, as well as in Hong Kong Chinese (14 - 18). In our study, mutant CAT-262TT genotype was detected in $6.33 \%$ BA patients and $7.69 \%$ healthy controls. The distribution of genotypes and alleles of CAT C-262T SNP was not significantly different between BA patients and controls in our study. Also, no differences were observed after stratification of the subjects by sex. Our results are in accordance with the results obtained by Mak et al. (18), Polonikov et al. (19) and Wenten et al. (20). However, Polonikov et al. suggested that another CAT A-21T (rs793316) SNP was associated with increased oxidative stress and increased BA risk due to decreased enzyme activity (19), but some other studies failed to reveal this association $(18,21)$. The homozygous CAT C-262T variant was associated with BA in the Slovak children (13). Furthermore, white children of Hispanic origin, carriers of genotypes with the mutant CAT-262T allele (CT or TT), were at an increased risk for new onset of asthma compared to the children who were homozygous for the common allele
(CAT-262C), while among non-Hispanic white children this polymorphism was not associated with BA risk (22).

Even that the catalase SNPs are not intensively studied in BA, results available in the literature are very contradictory. These discrepancies partially may be the result of ethnical differences among the subjects involved in these studies. Furthermore, the differences between the studies could be due to gene-gene and geneenvironment interactions in complex diseases, such as BA. Thus, further studies performed in different populations and on the larger sample sizes are needed in order to elucidate the role of genetic polymorphisms in catalase gene in the pathogenesis of BA.

\section{CONCLUSION}

This is the first study that examined CAT C-262T (rs1001179) SNP in Serbian patients with BA. The results obtained in this study show that the biallelic SNP at the position -262 in the catalase gene is not associated with BA in the Serbian population.

\section{ACKNOWLEDGMENT}

This work was supported by the Ministry of Education, Science and Technological Development of the Republic of Serbia (grant number III41018). 


\section{References}

1. Comhair SA, Erzurum SC. Redox control of asthma: molecular mechanisms and therapeutic opportunities. Antioxid Redox Signal 2010; 12(1):93-124.

https://doi.org/10.1089/ars.2008.2425

2. Ray PD, Huang BW, Tsuji Y. Reactive oxygen species (ROS) homeostasis and redox regulation in cellular signaling. Cell Signal 2012; 24(5):981-90. https://doi.org/10.1016/j.cellsig.2012.01.008

3. Cho YS, Moon H. The Role of Oxidative Stress in the Pathogenesis of Asthma. Allergy Asthma Immunol Res 2010; 2(3):183-7.

https://doi.org/10.4168/aair.2010.2.3.183

4. Zelen I, Djurdjevic P, Popovic S, Radivojevic S, Stojanovic M, Baskic D. Superoxide dismutase, catalase and glutathione peroxidase activities in lymphocities and in serum of patients with chronic lymphocytic leukemia. Medicus 2007; 8(2):43-8.

5. Quan F, Korneluk RG, Tropak MB, Gravel R., Isolation and characterization of human catalase gene. Nucleic Acids Res 1986; 14:5321-35. https://doi.org/10.1093/nar/14.13.5321

6. Kodydková J, Vávrová L, Kocík M, Žák A. Human catalase, its polymorphisms, regulation and changes of its activity in different diseases. Folia Biol (Praha) 2014; 60(4):153-67.

7. Bohanec Grabar P, Logar D, Tomsic M, Rozman B, Dolzan V: Genetic polymorphisms modifying oxidative stress are associated with disease activity in rheumatoid arthritis patients. Dis Markers 2009; 26(1):41-8.

https://doi.org/10.1155/2009/147356

8. Ghosh S, Janocha AJ, Aronica MA, Swaidani S, Comhair SA, Xu W et al. Nitrotyrosine proteome survey in asthma identifies oxidative mechanism of catalase inactivation. J Immunol 2006; 176(9):5587-97. https://doi.org/10.4049/jimmunol.176.9.5587

9. Novak Z, Nemeth I, Gyurkovits K, Varga SI, Matkovics $B$. Examination of the role of oxygen free radi- cals in bronchial asthma in childhood. Clin Chim Acta 1991; 201:247-51.

https://doi.org/10.1016/0009-8981(91)90375-M

10. Kim TH, Hong JM, Oh B, Cho YS, Lee JY, Kim HL et al. Genetic association study of polymorphisma in the catalase gene with the risk of osteonecrosis of the femoral head in the Korean population. Osteoarthritis Cartilage 2008;16(9):1060-6.

https://doi.org/10.1016/j.joca.2008.02.004

11. Ahn J, Gammon MD, Santella RM, Gaudet MM, Britton JA, Teitelbaum SL et al. Associations between breast cancer risk and the catalase genotype, fruit and vegetable consumption, and supplement use. Am J Epidemiol 2005;162(10):943-52.

https://doi.org/10.1093/aje/kwi306

12. Nadif R, Mintz M, Jedlicka A, Bertrand JP, Kleeberger SR, Kauffmann F. Association of CAT polymorphisms with catalase activity and exposure to environmental oxidative stimuli. Free Radic Res 2005; 39:1345-50.

https://doi.org/10.1080/10715760500306711

13. Babusikova E, Jesenak M, Evinova A, Banovcin P, Dobrota D. Frequency of Polymorphism $-262 \mathrm{C} / \mathrm{T}$ in Catalase Gene and Oxidative Damage in Slovak Children With Bronchial Asthma. Arch Bronconeumol (2013);49(12):507-12.

https://doi.org/10.1016/j.arbr.2013.10.009

14. Pask R, Cooper JD, Walker NM, Nutland S, Hutchings J, Dunger DB et al. No evidence for a major effect of two common polymorphisms of the catalase gene in type 1 diabetes susceptibility. Diabetes Metab Res Rev 2006;22:356-60.

https://doi.org/10.1002/dmrr.628

15. Zarbock R, Hendig D, Szliska C, Kleesiek K, Götting C. Pseudoxanthoma elasticum: genetic variations in antioxidant genes are risk factors for early disease onset. Clin Chem 2007;53:1734-40. https://doi.org/10.1373/clinchem.2007.088211

16. Warchoł $\mathrm{T}$, Lianeri $\mathrm{M}$, Wudarski $\mathrm{M}$, Łacki JK, Jagodzinski PP. Catalase $-262 \mathrm{C} \mathrm{T}$ polymorphism in 
systemic lupus erythematosus in Poland. Rheumatol Int 2008;28:1035-9.

https://doi.org/10.1007/s00296-008-0569-9

17. Suzen HS, Gucyener E, Sakalli O, Uckun Z, Kose G, Ustel D et al. CAT and C-262T and GPX1 Pro198Leu polymorphisms in a Turkish popula-tion. Mol Biol Rep 2010;37:87-92.

https://doi.org/10.1007/s11033-009-9540-4

18. Mak JC, Leung HC, Ho SP, Ko FW, Cheung AH, Ip MS, Chan-Yeung MM. Polymorphisms in manganese superoxide dismutase and catalase genes: functional study in Hong Kong Chinese asthma patients. Clin Exp Allergy 2006;36(4):440-7. https://doi.org/10.1111/j.1365-2222.2006.02458.x

19. Polonikov AV, Ivanov VP, Solodilova MA, Kozhuhov MA, Panfilov VI. Tobacco Smoking, Fruit and Vegetable Intake Modify Association Between 21A $>\mathrm{T}$ Polymorphism of Catalase Gene and Risk of Bronchial Asthma. Journal of Asthma 2009; 46(3): 217-24. https://doi.org/10.1080/02770900802492103

20. Wenten M, Gauderman WJ, Berhane K, Lin PC, Peters J, Gilliland F. Functional variants in the catalase and myeloperoxidase genes, ambient air pollution, and respiratory-related school absences: an example of epistasis in gene-environment interactions. Am J Epidemiol 2009; 170:1494-501. https://doi.org/10.1093/aje/kwp310

21. Despotovic M, Jevtovic Stoimenov T, Stankovic I, Pavlovic D, Sokolovic D, Cvetkovic T et al. Gene Polymorphisms of Tumor Necrosis Factor Alpha and Antioxidant Enzymes in Bronchial Asthma. Adv Clin Exp Med 2015; 24(2): 251-6. https://doi.org/10.17219/acem/40454

22. Islam $\mathrm{T}$, McConnell $\mathrm{R}$, Gauderman WJ, Avol E, Peters JM, Gilliland FD. Ozone, oxidant defence genes, and risk of asthma during adolescence. Am J Respir Crit Care Med 2008;177:388-95. https://doi.org/10.1164/rccm.200706-863OC 


\title{
Varijacija C-262T u genu za katalazu kod bolesnika sa bronhijalnom astmom
}

\author{
Milena Despotovićn ${ }^{1}$ Tatjana Jevtović Stoimenov ${ }^{1}$, Ivana Stanković \\ Jelena Bašić1, Branka Đorđević1, Dušica Pavlović1 \\ ${ }^{1}$ Univerzitet u Nišu, Medicinski fakultet, Institut za biohemiju, Niš, Srbija \\ ${ }^{2}$ Klinički centarNiš, Klinika za plućne bolestii TBC Knez Selo, Niš, Srbija
}

\section{SAŽETAK}

Bronhijalna astma (BA) je hronično zapaljensko oboljenje disajnih puteva u čijoj patogenezi oksidavini stres ima značajnu ulogu. Polimorfizmi pojedinačnih nukleotida (SNP) u genu za katalazu mogu dovesti do smanjenog antioksidativnog kapaciteta istog, a povećati rizik za razvoj BA. S obzirom na to da oksidativni stres ima značajnu ulogu u patogenezi BA i da katalaza ima ključnu ulogu u antioksidativnoj odbrani, cilj ovog istraživanja bio je da se ispita udruženost CAT C-262T polimorfizma sa BA u srpskoj populaciji.

Polimorfizam CAT C-262T određivan je primenom PCR-RFLP metode kod ukupno 170 ispitanika (79 bolesnikasa BA i 91 zdravih ispitanika).

Analiza raspodele genotipova nije pokazala statističk iznačajne razlike između obolelih od BA i zdravih ispitanika $(p>0,05)$. Takođe, razlike nisu pokazane ni primenom dominantnog ili recesivnog modela.

Raspodela CAT -262C and CAT -262T alela nije pokazala razlike između bolesnika i zdravih ispitanika(p = 0,715; OR=1,091; 95\% CI = 0,684-1,741). Dalja analiza raspodele genotipova i alela u odnosu na pol ispitanika nije se značajno razlikovala između obolelih od BA i zdravih ispitanika $(p>0,05)$.

Ovo je prva studija koja je proučavala CAT C-262T (rs1001179) polimorfizam kod obolelih od BA u srpskoj populaciji. Dobijeni rezultati su pokazali da bialelni polimorfizam u položaju -262 gena za katalazu nije udružen sa BA u srpskoj populaciji.

Ključnereči: bronhijalna astma, SNP, katalaza, oksidativni stres 